\title{
Mídia e revolução em Portugal: discurso e poder no boletim Movimento (1974-1975)
}

\author{
Adriano Lopes GOMES ${ }^{1}$ \\ Carla BAPTISTA ${ }^{2}$
}

\begin{abstract}
Resumo:
Este artigo analisa a forma como o Movimento das Forças Armadas (MFA) organizou a sua comunicação midiática no período subsequente à revolução de 25 de Abril de 1974, em Portugal. Focamos o boletim Movimento, elaborado pelos militares revoltosos, procurando situar quais os topoi construídos pelo discurso jornalístico revolucionário para fomentar a mobilização popular. Iremos situar o Movimento no contexto das transformações que afetaram o conjunto da mídia portuguesa entre 1974-1975 e retraçar as tentativas para definir uma política de informação ao serviço da revolução. A partir da análise discursiva de cinco editoriais, identificamos as linhas de verdade que constroem a argumentação do MFA: foi simultaneamente intérprete das aspirações populares; guardião das conquistas da revolução e garantia do cumprimento das políticas socializantes.
\end{abstract}

Palavras-chave: 25 de Abril. Movimento das Forças Armadas (MFA) de Portugal. Mídia. Revolução. Boletim Movimento.

\section{Media and revolution in Portugal: discourse and power in the Movimento newspaper (1974-1975)}

Abstract:

This article analyzes how the Movimento das Forças Armadas (MFA) [Armed Forces Movement] organized its media communication in the period following the revolution of April 25 in Portugal. We focused on the newspaper Movimento, elaborated by the rebellious military, locating the topoi produced by the revolutionary journalistic discourse to promote popular mobilization. The Movimento is situated in the context of the transformations affecting the Portuguese media between 1974-1975 and the attempts made to define an information policy at the service of the revolution. From the discursive analysis of five editorials, we identify the lines of truth in the centre of MFA's argumentation: the movement was simultaneously an interpreter of popular aspirations; a guardian of the achievements of the revolution and a guaranteeing to the fulfilment of the socialist's policies.

Keywords: April 25. Armed Forces Movement (MFA) of Portugal. Media. Revolution. Newspaper Movimento

\section{Medios y revolución en Portugal: discurso y poder en el boletín Movimiento (1974-1975)}

\section{Resumen:}

Este artículo analiza la forma como el Movimento das Forças Armadas (MFA) [Movimiento de las Fuerzas Armadas] organizó su comunicación mediática en el período posterior a la revolución del 25 de Abril de

\footnotetext{
${ }^{1}$ Pós-doutor pela Universidade Nova de Lisboa (Portugal), professor do Departamento de Comunicação Social e do Programa de Pós-Graduação em Estudos da Mídia da Universidade Federal do Rio Grande do Norte (Brasil). Coordenador do Grupo de Pesquisa Comunicação, Cultura e Mídia. E-mail: adrianoufrn@gmail.com
}

\footnotetext{
${ }^{2}$ Doutora, professora da Universidade Nova de Lisboa. E-mail: carlamariabaptista@gmail.com
} 
1974 en Portugal. Enfocamos el boletín Movimiento, elaborado por los militares revueltos, buscando situar los topoi construidos por el ejército no discurso periodístico revolucionario para fomentar la movilización popular. Vamos a colocar el Movimiento en el contexto de los cambios que han afectado a la totalidad de los medios de comunicación portugueses entre 1974-1975 y rastrear los intentos de definir una política de información en apoyo de la revolución. A partir del análisis discursivo de cinco editoriales, identificamos las líneas de verdad que construyen la argumentación del MFA: ha sido simultáneamente intérprete de las aspiraciones populares; guardián de las conquistas de la revolución y garantía del cumplimiento de las políticas socializantes.

Palabras clave: 25 de Abril. Movimiento de las Fuerzas Armadas (MFA) de Portugal. Medios de comunicación. Revolución. Boletín Movimiento.

\section{Introdução}

As considerações em torno da verdade sempre acompanharam as discussões sobre o jornalismo como uma prerrogativa sem a qual não se pode legitimar a natureza dos fatos. Ao se colocar o tema em reflexão, surgem alguns elementos que estão na baila das cogitações da atividade jornalística que seriam necessárias ao entendimento de qualquer formulação epistêmica: o que é a verdade? Que realidade fragmentada é essa de tal maneira que se perceba o mundo como uma verdade parcial e que, invariavelmente, requisitará do sujeito outras informações para adicioná-las na ordem dos acontecimentos? O ideal da verdade é algo que está na linha de frente como "primeira obrigação" do jornalismo, no dizer de Kovach e Rosenstiel (2003). Arendt (2003) dedicou-se a mapear os tensionamentos entre a verdade e a mentira na política, em cujas reflexões nos apoiamos para correlacioná-las aos eventos midiáticos, ora em tela, com vistas à construção da verdade jornalística.

Neste artigo, procuramos delinear tais questionamentos à guisa de contribuição aos estudos da mídia associando o tema à noção de parresia sob a ótica da práxis jornalística. Nosso objeto de juízo analítico é o boletim Movimento, órgão de imprensa oficial do Movimento das Forças Armadas de Portugal (MFA), editado e publicado em Lisboa, que durante quase um ano circulou por todo o país como forma de divulgar e consolidar os ideais revolucionários do 25 de Abril de 1974, data historicamente conhecida como a Revolução dos Cravos. Aqui não importa considerar elementos que pontuaram a história, o desencadeamento que levou à revolta militar, nem os desdobramentos que sucederam à revolução. Interessa-nos, tão somente, identificar as vozes presentificadas na retórica textual de cuja subjacência pode-se inferir as marcas de "verdade" que se foi construindo como representação simbólica no solo português pelas páginas de o Movimento. 
As imagens da revolução portuguesa ocorrida no dia 25 de Abril de 1974 são conhecidas e circularam pelo mundo inteiro. Entre os lugares estratégicos tomados pelos revolucionários constavam a antena emissora da Rádio e Televisão de Portugal (RTP), os estúdios da televisão portuguesa e as instalações da Emissora Nacional e do Rádio Clube Português. Foi a partir destes dois grandes meios de comunicação de massas - a televisão e a rádio - que os portugueses foram informados sobre o desenrolar dos acontecimentos, através da leitura de comunicados escritos pelo Movimento das Forças Armadas (MFA) e lidos por alguns dos jornalistas mais conhecidos da época ${ }^{3}$, explicando genericamente a natureza do golpe militar e apelando aos cidadãos para se manterem em casa.

A multidão anônima de telespectadores e de ouvintes tornou-se pela primeira vez na história da mídia portuguesa uma multidão desobediente, instalando uma contiguidade real entre o espaço midiático e a rua. A televisão do anterior regime convocava por vezes a multidão, servindo-se dos seus corpos e dos seus rostos como figurantes de cerimônias públicas, sempre privados de voz. Era uma multidão muda e passiva, confinada a gestos de aplauso aos atos do regime. Esses rígidos protocolos de representação discursiva e visual foram quebrados no dia 25 de Abril de 1974. Nas horas seguintes à madrugada do golpe, milhares de pessoas ocuparam os espaços emblemáticos da cidade, encorajando os militares revoltosos. O apoio popular espontâneo e massivo foi decisivo para o desfecho dos acontecimentos, dissuadindo as forças que se mantinham leais ao regime de uma resposta violenta que certamente teria provocado centenas de baixas civis e alterado drasticamente o perfil histórico pacífico da Revolução dos Cravos.

A adesão popular foi feita a uma promessa incerta construída sobre uma ideia mobilizadora: o fim da ditadura, o início da liberdade. A expressão do povo português concretizou-se numa figuração com rosto e voz, equilibrando as linhas de uma representação midiática até aí muito distorcida e desigual. Quando falamos de revolução na mídia portuguesa é importante sublinhar o movimento inaugural para a conquista de visibilidade da ação política popular no espaço público. Este movimento, inicialmente aberto pelos militares, acabou sendo conquistado aos militares, em parte replicando a forma como estes tomaram o poder. Será incorporado no trabalho jornalístico como um apelo ao qual os meios de comunicação social responderam em função de circunstâncias diversas e sofrendo já diversas manipulações.

\footnotetext{
${ }^{3}$ Luís Filipe Costa e Joaquim Furtado no Rádio Clube Português, Fernando Balsinha e Fialho Gouveia na RTP.
} 
Os impactos do 25 de Abril de 1974 na mídia têm sido um dos pontos focais da historiografia portuguesa recente sobre a revolução, desde a análise pioneira de Mário Mesquita (1994) procurando periodizar e categorizar a natureza das relações entre a esfera política e o campo jornalístico, até aos trabalhos que fazem o levantamento dos acontecimentos ocorridos em meios específicos. Neste âmbito, estão já documentados os casos do jornal República, Expresso, Diário de Notícias e Jornal Novo (FIGUEIRA, 2007; GOMES, 2014), Jornal de Notícias (LIMA, 2011), (RIBEIRO, 2002; SANTOS, 2005) e RTP (CÁDIMA, 2001; REZOLA; GOMES, 2014). Estes estudos apontam para um clima de intensa conflitualidade e luta pelo controle dos meios de comunicação social como parte estruturante do processo revolucionário e posterior institucionalização da democracia em Portugal. Os militares obreiros de abril são atores centrais nessa transição marcada por vários acontecimentos, desde a criação da Comissão “AD HOC” para a Comunicação Social (junho de 1974), investida de novos poderes censórios, concomitante à criação da $5^{\mathrm{a}}$ Divisão do Estado-Maior-General das Forças Armadas, órgão de propaganda dos militares dotado de amplos recursos materiais, incluindo uma poderosa estratégia comunicativa, notadamente do Programa de Televisão do MFA, o Programa de Rádio do MFA e a publicação do Boletim Movimento do MFA. Segundo Veiga (2014, p. 156), “estes recursos traduziam, de uma forma inequívoca, a reconfiguração da própria esfera militar, que, num regime de transição, reclamava um papel de natureza interventiva mesmo nas esferas política e civil”.

\section{Movimento: jornal propagandístico e revolucionário}

Partimos do princípio de que o Movimento era um veículo de caráter propagandístico revolucionário, mas que se utilizava do modelo convencional do jornalismo impresso para chegar ao público. Surgido em setembro de 1974, o boletim destinava-se inicialmente a fazer a defesa do programa do MFA e das reivindicações exclusivamente militares. À medida que as clivagens crescentes no seio do próprio MFA iam pulverizando a coesão inicial sobre os rumos da revolução, a tendência foi para a autonomização do corpo responsável pela edição do jornal, algumas vezes à revelia da própria hierarquia. São estas tensões que tornaram o Movimento um produto extremamente interessante, ilustrativo da pulverização ideológica que, de forma abrupta, logo acompanhou o rescaldo dos primeiros dias do golpe revolucionário. Veiga (2014) refere que, de instrumento de coesão inicial, o Movimento se tornou numa fonte de divisão entre os militares e foram tomadas iniciativas para tentar encerrar a publicação. Ao invés, 
alargou a sua distribuição (gratuita, nas ruas) e fez dos leitores não militares (o povo) o seu principal instrumento de legitimidade. Assim, embora no nível discursivo o boletim reflita muitas das leis e técnicas da propaganda política, como veremos adiante, também é possível perspectivar na sua evolução um caminho muito idêntico ao que se passava em vários outros órgãos de comunicação social sem uma natureza propagandística. A pulsão jornalística, tendencialmente orientada para acolher e discutir visões diferenciadas sobre a natureza do regime, coexistiu com a difusão persuasiva do modelo de sociedade e democracia defendido pelo grupo dos militares mais radicalizados. Esta elasticidade, fruto do contágio com a dinâmica da revolução, é visível em outros aspectos do boletim, sobretudo na sua linha gráfica, que desde os primeiros números integrou colaborações do cartunista João Abel Manta, um dos artistas que melhor soube exprimir visualmente as alegrias e as decepções de abril.

Vamos focar-nos sobre questões do discurso nos editoriais de o Movimento, considerando-os legítimos para os fins a que se propõe este artigo. $\mathrm{O}$ editorial atende a um tipo de gênero textual utilizado na imprensa, objetivando informar sem o compromisso da neutralidade e da imparcialidade, tão propalados como ideais a serem perseguidos pelo jornalista. Ao contrário, é nos editoriais que a empresa ou o próprio veículo deixa clara a sua opinião sobre determinado assunto que merece maior relevo em uma dada edição. Nos editoriais vamos identificar uma articulação de jogo semântico como se fora um exercício de poder para atestar o firme propósito de convencimento alheio sobre os modos de pensar a respeito de um tema que provoca e afeta a sociedade e que, em última instância, alcança os interesses institucionais. Assim, os editoriais destinam-se à opinião pública, tanto quanto fomentam a sua adesão no que respeita à "verdade" ali esboçada. Se há essa intriga de forças, há, de modo semelhante, os modos imbricados de ideologia e poder. Melo (2003) destaca essa particularidade, assim afirmando:

\footnotetext{
Sabendo que dispõem dessa força e que encontram correspondência no aparelho estatal, as instituições jornalísticas atribuem à produção de editoriais uma atenção toda especial que supõe plena integração entre as políticas da empresa e os interesses corporativos que defendem. (MELO, 2003, p. 105).
}

Por conterem tais "interesses corporativos", não é por outro motivo que os editoriais, via de regra, vêm sempre nas primeiras páginas, são apócrifos, geralmente impessoais e apelam para o senso racional com dados argumentativos. No boletim Movimento, os editoriais eram apresentados na capa, na margem esquerda, ocupando a 
coluna inteira. Por questões de espaço gráfico, em algumas edições iniciavam na primeira página e concluíam nas páginas internas.

Por outro lado, para pensarmos a dimensão do jornalismo partiremos da noção de parresia conforme a discute Foucault (2011). A parresia é esse conceito que nos ajudará a compreender qual a relação que o jornalista deve ter com a verdade - que aqui não se relaciona aos pressupostos do estilo jornalístico. Desse modo, os veículos de comunicação devem assumir a verdade como parâmetro profissional a partir da ideia da parresia como o falar-franco ou da coragem da verdade, como afirmou Foucault (2011). Mesmo que tais abordagens nos permitam uma interpretação dentro do espectro do jornalismo diário, é possível compreender o fenômeno da parresia nas páginas de o Movimento, exatamente porque ali fundava-se o princípio de assentamento de uma ideologia em torno da qual se preconizavam e para a qual se voltavam como forma de assegurar o pensamento do MFA junto da população portuguesa.

Mesmo que estejamos assumindo que o MFA não fazia jornalismo, é lícito dizer que o formato adotado pelos editores para propalar as ideias estava próximo da configuração jornalística. Podemos relacionar o editorial de o Movimento com o pressuposto implícito de querer dizer e defender a sua "verdade", sendo essa de matriz ideológica. Como o conceito é amplo e obedece a uma gradação de ilações, partiremos da conjetura de que a ideologia pressupõe a conscientização de uma "verdade" que se quer política para permitir a adesão pública. É nesse tecido de enunciados, discursos e sentidos que se constrói a linguagem e se insinua o poder, cuja reverberação nutre o pensamento social e dele formulam-se as convicções populares.

Pelo exposto, é evidente associar a noção de parresia com ideologia, posto que entre uma e outra há interesses explícitos ou velados cujos compromissos corroboram diretamente com a "verdade". Porém, que verdade pode-se inferir ao analisarmos os editoriais de o Movimento?

\section{O dito e o não dito pelo Movimento: análise dos editoriais}

As análises dos dados obedecerão a um recorte temporal que reúne cinco edições do boletim Movimento que vão de setembro de 1974 a agosto de 1975, período de circulação. É uma escolha metodológica não analisarmos todos os números editados pelo MFA por algumas razões: 1) Os discursos passam a ser recorrentes entre um editorial e outro, o que implica dizer que eles se repetem na materialidade textual; 2) O corpus de análise poderia cair à exaustão; 3) A necessidade de maturação discursiva entre as 
veiculações, uma vez que as edições eram quinzenais, o que demandaria um olhar longitudinal mais crítico. Interessamo-nos em ver a primeira e a última edição em um espaço de tempo de um ano. Quanto às demais edições, a escolha foi aleatória, obedecendo a uma margem aproximada de três meses entre uma e outra.

O boletim Movimento, cujos editoriais analisaremos a seguir, foi editado pela Comissão Coordenadora do Programa do MFA, de publicação quinzenal, em formato tabloide ${ }^{4}$, circulando de 9 de setembro de 1974 a 14 de agosto de 1975, totalizando 25 edições. As colunas fixas concentravam-se em um Editorial (não assinado), sempre na primeira página e, alguns, eram concluídos nas páginas posteriores. Os temas eram essencialmente de esclarecimento político e abordavam assuntos relacionados com o movimento revolucionário, à descolonização e aos problemas sociais e econômicos decorrentes de 48 anos de Estado Novo. Uma componente mais noticiosa dava conta das ações das campanhas de dinamização cultural nas aldeias portuguesas ou referia exemplos inspiradores de outras revoluções em curso no mundo.

O boletim Movimento apresenta-se como um artefato e uma via de acesso à construção ideológica que sustenta o projeto revolucionário do MFA. O plano é desenhado com rigor matemático-militar, apresentando o jornalismo como a narrativa mais adequada para traduzir as representações desse projeto e operacionalizar a sua dimensão moral, ou seja, para fazer a política (e não a história ou a atualidade) do presente. Isto posto, passemos à análise do material coletado.

a. Editorial 1 (edição número 1, de 1 de setembro de 1974):

O primeiro editorial de o Movimento foi destinado mais para tornar explícitos os objetivos de um órgão de divulgação impresso como forma de demarcar um terreno em que as Forças Armadas e Militarizadas deveriam atuar no processo de democratização com a "isenção partidária" 5 sem, contudo, presumir-se um movimento de "isenção política"6 "na luta pela construção de um Portugal Livre, Democrático e Progressivo"7 . Para tanto, faz uso de uma retórica em que apela para a aliança MFA-Povo, estabelecendo, desde o seu nascedouro, a parceria com as bases populares para o cumprimento do programa definido pela Comissão Central, apresentando-se como "guardião" dos interesses do povo nos destinos diante de possíveis "manobras e acções contra-

\footnotetext{
${ }^{4}$ Formato tabloide: $30,5 \times 42,5 \mathrm{~cm}$.

${ }^{5}$ Linha 55 da página 1.

${ }^{6}$ Linha 54 da página 1.

${ }^{7}$ Linhas 6 e 7 da página 1.
} 
revolucionárias", , como que a dar um recado sob forma de alerta: "venham de onde vierem" ". Nesse editorial, pudemos identificar a clara evocação da presença popular como aliada da disseminação dos ideais revolucionários com vistas a desfazer, desde cedo, a concepção monolítica de que se tratava de um movimento político-partidário. Por outro lado, o próprio MFA busca ocupar o seu lugar de herói da causa revolucionária quando enfatiza que é o "guardião do cumprimento integral do seu programa, que há de restituir ao seu país as instituições democráticas nele inscritas [...]"10. O vilão, nessa esfera textual, passa a ser as "forças conservadoras", traduzidas como "fascistas". Nesse jogo de forças que se procura instaurar o poder vê-se a presença arquetípica entre o bem e o mal. Bakhtin (1999, p. 36) já havia assinalado que a palavra é “o fenômeno ideológico por excelência, ela é o modo mais puro e sensível de relação social", por meio da qual passamos a entender a associação entre locutor e interlocutor, bem como as estruturas da linguagem. Com base nessa assertiva, Brandão $(2004$, p.11) destacou: “[...] a linguagem é lugar de conflito, de confronto ideológico, não podendo ser estudada fora da sociedade, uma vez que os processos que a constituem são histórico-sociais". Assim, o Editorial 1 instaura um chamamento coletivo do MFA para um contrato com o povo português no sentido de marcharem juntos rumo a um cenário político no país.

b. Editorial 2 (edição número 7, de 24 de dezembro de 1974):

Mesmo transcorridos três meses da primeira edição, esse editorial, com o título “As Forças Armadas e a Nação", segue a linha anterior e procura recuperar a importância popular na implementação da democracia em Portugal. Inicia superlativizando o 25 de Abril de 1974 como uma data "memorável" e um "exemplo quase único no mundo"11 em que as Forças Armadas deram um golpe militar. Faz crítica à iniciativa de parlamentares, partidos políticos e algumas organizações conservadoras civis, o que veio a se afirmar como "setembro silencioso", mostrando-a como um insucesso. Segundo destacado em vários pontos do texto, o ideal do movimento militar deve estar atrelado ao sentido democrático e progressista na disseminação do projeto em suas bases por meio do que fora designado de "Dinamização Cultural"12, assim destacando: "Os militares têm de

\footnotetext{
${ }^{8}$ Linha 43 da página 1.

${ }^{9}$ Linha 44 da página 1.

${ }^{10}$ Linhas 40 a 42 da página 1.

${ }^{11}$ Linhas 3 e 4 do Editorial da página 1.

${ }^{12}$ Esse projeto deu início às chamadas Campanhas de Dinamização Cultural, uma ação das Forças Armadas para gerar consciência política junto à população e promover mudanças estruturais em diversos segmentos sociais.
} 
utilizar o seu imenso prestígio e o seu poder para impor reformas onde elas não surgiram, para corrigir injustiças onde elas persistiram, para actuar no seio do povo (em sincronia com as estruturas governamentais, sempre que possível) ${ }^{13}$. Três palavras interagem com o conceito de verdade que se procura passar nesse editorial: "prestígio" (antecedido do adjetivo "imenso"), "poder" (ou seja, a demarcação do território classificado no Editorial 1) com vistas a "impor" (isto é, obrigar) reformas porque o país estaria marcado por injustiças não corrigidas. O MFA coloca-se, portanto, como o "justiceiro" do povo e evoca, em chamamento entre parênteses, a participação do governo "sempre que possível”, ou seja, quando for conveniente, necessária e pertinente para a consecução do aludido projeto de democracia. Para justificar a ampla aliança Povo-MFA, as Forças Armadas concentrariam os seus esforços na implementação de programas nas áreas de saúde, habitação, agricultura, engenharia civil e transportes. Tal estratégia nos campos é de apelo popular, pois sinaliza questões "progressistas", dedicadas em diversas passagens do editorial ${ }^{14}$. Que apelo maior, senão esse, para arregimentar o interesse alheio da participação pública da causa em evidência? O que está em destaque no discurso, denotando o conceito de verdade, é que sem os militares o 25 de Abril não teria sido possível e que, sem eles, de igual modo não será possível executar os projetos de democracia e projeto. Com outras palavras, pode-se entender: os militares foram indispensáveis nesse processo e do povo português necessita apoio e adesão à causa.

\section{c. Editorial 3 (edição número 14, de 8 de abril de 1975)}

Nesse Editorial 3, cujo título é "O voto e a revolução", tem-se transcorrido quase um ano da revolução de 25 de Abril de 1974, que, conforme assinala o texto, levou à "queda da odiosa ditadura fascista" 15 . Ao lado da evocação da palavra "odiosa", assinala o largo período de "repressão das liberdades de cidadania, de mentira e de falsificação de actos eleitorais [...]"16, como tentativa de justificar aquele sentimento que, mais adiante, vai concluir que foi um passado que deixou uma "marca trágica" ${ }^{17}$. Como contraponto a tais argumentos, o editorial faz um apelo recorrente à participação do povo português nas eleições que se aproximavam, anos depois de estar distanciado da escolha dos seus representantes políticos na Assembleia Constituinte. Coloca o voto como "uma arma do

\footnotetext{
${ }^{13}$ Linhas de 23 a 29 da página 6 (continuação do Editorial).

${ }^{14}$ Linhas 2, 6, 8 e 13 da página 6 (continuação do Editorial).

${ }^{15}$ Linhas 2 e 3 da página 1.

${ }^{16}$ Linhas de 9 a 13 da página 1.

${ }^{17}$ Linha 22 da página 1.
} 
Povo" 18 para vencer os "muitos inimigos"19 que, no caso, são os considerados "fascistas". Por seis vezes consecutivas, o texto expõe a expressão "temos que ser lúcidos" 20 com vistas ao futuro político da nação, no sentido do comparecimento às assembleias de votação e, como efeito, votar consciente. Caso contrário, seria uma traição ao 25 de Abril, pelo dever não cumprido. O uso simbólico da palavra "arma" (o voto) denota a forma de assaltar o passado dos inimigos do povo, passado esse apontado como difícil, duro, embaraçoso e sem democracia. Aquela seria a hora do voto consciente, de cuja omissão representaria uma afronta aos princípios revolucionários que se tentavam novos ares ao país.

d. Editorial 4 (edição número 23, de 11 de julho de 1975).

O editorial reúne, já no título, três palavras que estarão no arcabouço textual como um projeto de "movimento de libertação"21: MFA, povo e revolução. Assim como nos anteriores, nesse editorial busca-se o reconhecimento popular na estratégia de adesão aos princípios revolucionários, conferindo ao povo um poder capaz de o conduzir ao "socialismo". Não obstante em seu primeiro editorial o boletim Movimento ter se apresentado como apartidário (o que não significaria um movimento apolítico), aqui expõe sua opção ideológica pela causa social, assim afirmando: "nenhum socialismo existe fora do poder exercido pelas massas populares; nenhum socialismo será possível no quadro do aparelho do Estado Burguês" ${ }^{22}$. Como se sabe, o socialismo é uma doutrina política que tem sua ideologia baseada na distribuição equilibrada de propriedades e riquezas e é sobre ela que o MFA pretende se apoiar a partir da tomada de partido, claramente explicitado nessa passagem do texto. Porém, evidencia que tal projeto de estado social só será possível com a presença e a participação das "massas populares"23, com vistas aos avanços para se alcançar o poder socialista. É difícil separar o ideal socialista, enquanto opção política, de um partido socialista que defende seus princípios. Ainda que no Editorial 1 o Movimento tenha se posicionado "apartidário", com esse editorial percebe-se o seu engajamento nas lutas do Partido Socialista (PS). O editorial ainda apela para a vigilância do povo no sentido de não se permitir o "dirigismo" 24 , para

\footnotetext{
${ }^{18}$ Linhas 104 e 105 da página 3 (continuação do Editorial).

${ }^{19}$ Linha 4 da página 3 (continuação do Editorial).

${ }^{20}$ Linhas 38, 44, 52, 63, 71 e 84 da página 3 (continuação do Editorial).

${ }^{21}$ Linhas 34 e 35 da página 1.

${ }^{22}$ Linhas 12,13 e 14 da página 1.

${ }^{23}$ Linha 18 da página 1.

${ }^{24}$ Linha 20. "Dirigismo" é compreendido como a direção do Estado em todas as ações da sociedade civil.
} 
não se confundir a dinâmica revolucionária com a dinâmica "putchista"25. Ou seja, o MFA colocava-se, no texto, como um movimento que tinha o papel de resguardar os interesses do povo para se evitar submissões e retrocessos, projeto que só seria possível se o próprio povo estivesse consciente de tais prerrogativas. E faz uma espécie de contrato por meio da aliança MFA-Povo, a reivindicar um crédito de confiança nos militares para se implementar o referido projeto de liberdade para uma sociedade "justa e livre" 26 e para garantir o processo revolucionário. Portanto, no texto assenta-se o socialismo como uma postura ideológica para estabelecer avanços e tornar a sociedade mais justa no mecanismo de recuperação dos 48 anos enfrentados à custa de dificuldades.

e. $\quad$ Editorial 5 (edição número 25, de 14 de agosto de 1975).

O editorial do último boletim Movimento em circulação reflete bem as dificuldades sentidas pelo MFA em manter acesos os ideais revolucionários de 25 de Abril de 1974. Embora não seja nosso objeto de estudo, no artigo imediatamente ao lado do editorial, o MFA alerta para a situação de crise que Portugal enfrentava pela existência de "manobras contrarevolucionárias" (A SITUAÇÃO..., 1975, p. 1) 27. No início do texto, já é possível ver de forma evidente a afirmação: “A revolução portuguesa é uma revolução socialista" ${ }^{28}$ para defender os pressupostos de uma sociedade livre. Em seguida, reforça:

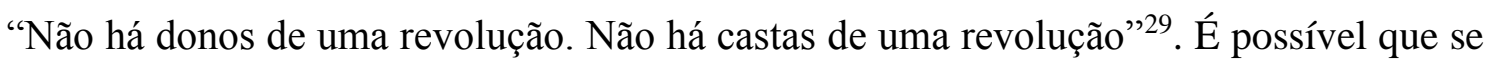
esteja fazendo alusão àqueles que, mais à frente, são tachados de "interessados no regresso a 24 de abril de 1974", isso porque eles "não desarmam, estão atentos, organizam-se e procuram utilizar e aproveitar tudo o que possa facilitar os seus sinistros objectivos" ${ }^{30}$. E assumem que esse processo “não é fácil”. Para se opor a esse contraste, o texto expõe a mesma frase por seis vezes: "temos que fazer um enorme esforço" 31 no sentido de salvaguardar os interesses do povo português relacionados com a educação, a pesca, a saúde, aos pequenos comerciantes. Por fim conclama os leitores para não se deixar "amedrontar" diante das responsabilidades à frente, para não se abater, ou seja, se se recrudescem as forças, os projetos revolucionários estariam falidos.

\footnotetext{
${ }^{25}$ Linha 21 da página 1. "Putchismo" é aqui entendido como uma ação aventureira, conspiração inconsequente e golpista.

${ }^{26}$ Linha 38 da página 1.

${ }^{27}$ Artigo “A situação política actual”, página 1, parágrafo 1.

${ }^{28}$ Linha 1 da página 1.

${ }^{29}$ Linha 5 da página 1.

${ }^{30}$ Linhas 27 e 28 da página 1.

${ }^{31}$ Linhas 48 (página 1), 1, 2, 4, 6 e 13 (página 10, continuação do Editorial).
} 


\section{As marcas de verdade do Movimento: as movências de sentido}

Após a análise dos editoriais, é imprescindível que retomemos o objetivo do presente trabalho com vistas a identificar as marcas de verdade presentificadas nas formações discursivas a partir dos textos. Convém dizer, em princípio, que as formações discursivas ocorrem em um contexto social por meio dos enunciados de um locutor que fala de algum lugar. O modo como os discursos se organizam está relacionado à voz discursiva que se pretende chegar ao outro com posições ideológicas definidas, ou que denota a subjetivação daquele a quem dirige (FOUCAULT, 1998). Cabe-nos revelar os mecanismos como tais discursos se formam e como se organizam na tessitura do corpo textual.

É pertinente dizer que as marcas de verdade aqui inscritas não são as únicas e muito menos se esgotam nelas mesmas. Apenas são "gestos de leitura" ou "efeitos de sentido entre os interlocutores", conforme Orlandi (1994, p. 53). Assim, entendemos a verdade como uma construção de sentidos na esfera da realidade social que sempre se dirige ao outro e dele pressupõe o seu consentimento. É nesse mecanismo que se estabelece o vínculo entre verdade e poder, como disse Foucault (1998, p.12): “A verdade não existe fora do poder ou sem poder". Quando alguém imputa a sua verdade ao outro, a rigor, quer ditar o modo pessoal de enxergar a realidade e arregimentar forças ao seu pensamento. Isso pode ser entendido como um dos dispositivos da ideologia.

Ao abordar a questão da verdade, Habermas (2004) se aproxima do que afirmamos anteriormente, destacando que a realidade é impregnada da linguagem. Ainda evidencia o autor (2004) que a garantia de enunciado sobre a verdade está com base em outros enunciados já aceitos, o que nos leva a admitir a possibilidade de interdependência discursiva temporal, sem, muitas vezes, estar assinalada pelo crivo. Assim destaca Habermas (2004):

\footnotetext{
O conceito discursivo de verdade deve, de um lado, levar em conta o fato de que a verdade de um enunciado - dada a impossibilidade do acesso direto a condições de verdades não interpretadas - não pode ser medida por "evidências peremptórias", mas apenas por razões justificadoras, se bem que jamais definitivamente obrigatórias (HABERMAS, 2004, p. 4546).
}

Já Arendt (2003) incursionou pela dialética entre verdade e mentira na política, em cujo contexto se inscreve o passado e o presente, apontando para uma memória que se funda nos princípios do totalitarismo histórico. Convém assinalar que a verdade preconizada pela autora está, por aproximação da natureza, na episteme da verdade 
jornalística em que ambas surgem por subjetivação da realidade, normativizando uma construção ontológica dos fatos. Diz Arendt (2003):

A era moderna, que acredita que a verdade nem é dada e nem é descoberta, mas produzida pela mente humana, apontou [...] para a verdade matemática, científica e filosófica como uma espécie comum de verdade racional distinta da verdade dos fatos (ARENDT, 2003, p. 231).

Isso posto, quais as marcas de verdade que o MFA intencionava passar ao povo português, por meio das páginas de o Movimento, ali presente nos editoriais? Quais as movências de sentidos que perpassavam pelas linhas textuais em torno das quais se inscreviam os dizeres dos seus enunciadores?

A partir da análise do corpus podemos perceber que há pelo menos três focos centrados na composição dos editoriais: 1) Foco no povo como elemento de interação de poderes. Nos cinco editoriais analisados é forte esse recurso paradigmático de espelhamento que pode ser traduzido nas expressões: "vocês são um de nós" ou "juntese a nós" para a redefinição de um novo país; 2) Foco no MFA na construção de uma imagem favorável e positiva da figura do militar, decantada pelos 48 anos de regime de exceção, e reconstrução do mesmo ícone em sua nova feição, sendo esta a de um militar que defende as causas populares, que luta por um país mais igualitário, digno e justo, que a partir daquele momento teria um papel social fundamental de ser o "herói", o "guardião", que representa o bem na dialética com o mal, retratado pelos "fascistas" ou os "inimigos da nação"; 3) Foco na construção das ideias socialistas como a garantia de um país mais justo. A partir da aliança MFA-Povo, e da confiança instaurada a partir desse acordo de fidelidade, o poder seria maior e crescente, de difícil recrudescimento das forças contrárias aos ideais revolucionários.

Com esse olhar, podemos estabelecer um "gesto de leitura" ao afirmar que os editoriais procuraram estabelecer uma verdade de que a revolução seria uma espécie de marca registrada do MFA e só os militares, junto com o povo, poderiam comandar os destinos do movimento para se alcançar os objetivos almejados, devendo enfrentar os opositores reacionários e os partidos de direita. Mas, para isso, contaria com o povo português, sem o qual ficaria difícil construir um novo Portugal, doravante assinalado pelos princípios socialistas de justiça e igualdade, em diversos segmentos da economia, da política, da saúde, da infraestrutura e da educação. Ou seja, sem a acreditação do povo, a ameaça das forças contrarrevolucionárias seria ainda maior, o que poria a perder todo o projeto de liberdade. 
A definição de uma política de verdade, nos moldes da parresia, envolve a prática do enfrentamento ideológico ou, como destaca Foucault (2011), de ferir o outro por não comungar do mesmo pensamento, chegando a situações extremas. Afirma o autor (2011):

Para que haja "parresia" é preciso que, dizendo a verdade, se abra, se instaure e se enfrente
o risco de ferir o outro, de irritá-lo, de deixá-lo com raiva e de suscitar de sua parte algumas
condutas que podem ir até a mais extrema violência. (FOUCAULT, 2011, p. 12).

Assim, os editoriais de o Movimento alcançavam duas esferas públicas distintas: os simpatizantes e os adversários do ideal revolucionário, sendo esses últimos o alvo de contendas por meio de palavras como "fascistas" e "inimigos". Quanto aos demais, os textos procuravam arregimentar um discurso de envolvimento com argumentos de mudança por um país melhor, se defendessem coletivamente a causa.

\section{Considerações finais}

As narrativas aqui expostas pelos editoriais nos levam a entender as formações discursivas que perpassaram pelas linhas e entrelinhas do período pós-revolucionário, balizando as marcas de "verdade", de modo a empoderar o povo português como principal aliado do MFA. Esta mistura de discursos persuasivos e informativos reflete a hibridização reinante na mídia portuguesa revolucionária e traduz o essencial do posicionamento ideológico do MFA, incluindo os seus paradoxos: a visão simultaneamente internacionalista e paroquial do mundo; a expressão de uma solidariedade transnacional promotora de novas alianças, mas mantendo o recorte nacionalista de muitas das categorias discursivas prevalecentes (povo, pátria); o desejo de liberdade, mas condicionada às sujeições discursivas conformes à leitura dos acontecimentos realizada pela cúpula dos militares; a construção de uma convergência construída e imaginada entre o povo e o MFA que resiste no discurso, mesmo quando se fragmentava no terreno das lutas concretas, conduzindo, no fim das contas, ao fim dessa mesma aliança e respectivo programa político.

\section{Referências}

ARENDT, Hannah. Entre o passado e o futuro. São Paulo: Perspectiva, 2003.

A SITUAÇÃO política actual. Movimento, Lisboa, n. 25, p. 1, 14 ago. 1975.

BAKHTIN, Mikhail. Marxismo e filosofia da linguagem. São Paulo: HUCITEC, 1999. 
BRANDÃO, Helena Nagamine. Introdução à análise do discurso. Campinas: Editora da Unicamp, 2004.

CÁDIMA, Francisco Rui. Os «media» na revolução (1974-1976). In: BRANDÃO DE BRITO, J.M. (coord.). O país em revolução. Lisboa: Editorial Notícias, 2011. p. 321358.

EDITORIAL. Movimento, Lisboa, n. 1, p. 1, 1 set. 1974.

EDITORIAL. Movimento, Lisboa, n. 7, p. 1 e 6, 24 dez. 1974.

EDITORIAL. Movimento, Lisboa, n. 14, p. 1 e 3, 8 abr. 1975.

EDITORIAL. Movimento, Lisboa, n. 23, p. 1, 11 jul. 1975.

EDITORIAL. Movimento, Lisboa, n. 25, p. 1 e 10, 14 ago. 1975.

FIGUEIRA, João . Os jornais como actores políticos: o Diário de Notícias, Expresso e Jornal Novo no verão quente de 1975. Coimbra: Minerva Coimbra, 2007.

FOUCAULT, Michel. A coragem da verdade. São Paulo: Martins Fontes, 2011.

FOUCAULT, Michel. Microfísica do poder. Rio de Janeiro: Graal, 1998.

GOMES, Pedro Marques. Os saneamentos políticos no "Diário de Notícias" no verão quente de 1975. Lisboa: Alêtheia Editores, 2014.

HABERMAS, Jürgen. Verdade e justificação: ensaios filosóficos. São Paulo: Edições Loyola, 2004.

KOVACH, Bill; ROSENSTIEL, Tom. Os elementos do jornalismo: o que os profissionais de jornalismo devem saber e o público deve exigir. Porto: Porto Editora, 2003.

LIMA, Helen. O Jornal de Notícias no Portugal democrático: luta política, deriva editorial e processo de renovação e conquista de públicos. In: CABRERA, Ana (org.). Jornais, jornalistas e jornalismo - séculos XIX e XX. Lisboa: Livros Horizonte, 2011. p. 205233.

MELO, José Marques de. Jornalismo opinativo. Campos do Jordão, SP: Editora Mantiqueira, 2003.

MESQUITA, Mario. Os meios de Comunicação Social. In: REIS, António (coord.). Portugal 20 anos de democracia. Lisboa: Círculo de Leitores, 1994. p 361-405.

ORLANDI, Eni Puccinelli. Discurso, imaginário social e conhecimento. Em Aberto, Brasília, DF, ano 14, n. 61, jan./mar. 1994.

REZOLA, Maria Inácia; GOMES, Pedro Marques (coord.). A revolução nos media. Lisboa: Tinta da China, 2014. 
RIBEIRO, Nelson. A Rádio Renascença e o 25 de Abril. Lisboa: Universidade Católica Editora, 2002.

SANTOS, Paula Borges. Igreja Católica, Estado e Sociedade 1968-1975: o caso Rádio Renascença. Lisboa: Imprensa de Ciências Sociais, 2005.

VEIGA, Ivo. A $5^{\text {a }}$ Divisão do Estado-Maior-General das Forças Armadas no processo revolucionário português. Modelos, apoios e antagonismos. Ler História, Lisboa, n. 67, p. 155-168, 2014.

Submetido em: 05.05.2018

Aprovado em: 01.02.2019 